Copyright (C) 2014 by Academic Publishing House Researcher

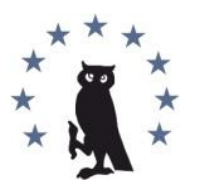

Published in the Russian Federation

European Researcher

Has been issued since 2010.

ISSN 2219-8229

E-ISSN 2224-0136

Vol. 79, No. 7-2, pp. 1310-1322, 2014

DOI: 10.13187/issn.2219-8229

www.erjournal.ru

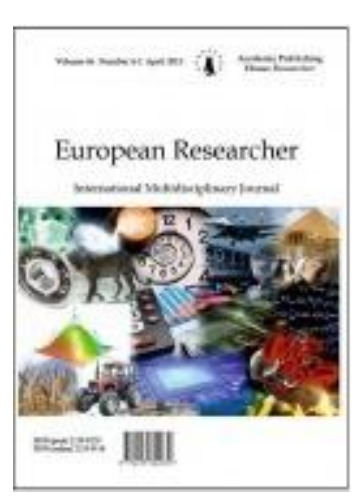

Historical sciences and archaeology

Исторические науки и археология

\title{
Ukrainian Historiography About the Solution of Agrarian Peasant Question in the Programs of Ukrainian Parties at the Beginning of 2oth Century, 1991-2013
}

\author{
Dmytro Kudinov
}

Taras Shevchenko National University of Kyiv, Ukraine

Department of history, doctoral candidate at the chair of ethnology and area study

Doctor of Philosophy

Service address: 6o Volodymyrska Street, City of Kyiv, Ukraine, 01033

Home address: 36/13 Kondratieva Street, Town of Sumy, Ukraine, 40030

E-mail: dmytro.kudinov@gmail.com

\begin{abstract}
The article is devoted to modern (post-Soviet) vision of Ukrainian historiographical science concerning resolving of agrarian peasant question, which is understood by the author as the complex of relations between the state and the peasantry, processes of the transformation of peasants' legal and property statuses and land use by peasants. That's why the historical partological study is considered in tight connection with peasant movement in Ukraine at the beginning of the 2oth century. The author reflects on the ideological essence of parties, which defined the specifics of their proposals both on land reform and on the change of peasants' estate status. Moreover, it is suggested to evaluate the attitude to agrarian question as one of the criteria for parties classification as left-wing, right-wing or centrist. Controversial issues regarding agrarian parts of party programs are investigated as well as the methods of struggle proposed by the parties.

Keywords: historiography; party; peasants; agrarian peasant question; agrarian program; socialists; nationalists; liberals.

\section{Introduction}

Important component of political parties' theoretical heritage at the beginning of the $20^{\text {th }}$ century was the development of agrarian issue, which influenced greatly the success of the parties' activity. In 1900 s the peasantry appeared on the foreground of social and political life. Receiving its loyalty meant the increase of the political parties' value. This made parties leaders to look for the most effective answers for the questions of land scarcity, securing of agrarian workers' labor rights, small farming, promoting of agricultural level, etc. Land and labour issues were suggested to solve in strong connection to the reform of future government system, guaranteeing of state and national rights of population, including peasants'.
\end{abstract}




\section{Literary review}

Political parties' programs at the beginning of the $20^{\text {th }}$ century now make an object of historical and political studies, some of which are partly or completely devoted to agrarian component of political platforms. Post-Soviet researches of this issue were summarized only in two historiographical works - the article of V. Lutsenko (1996) and monograph of V. Dubinskyi and O. Fedkov (2012). Moreover, these two works do not overlap in the selection of materials since V. Lutsenko analysed the researches of his contemporaries while V. Dubinskyi and O. Fedkov mostly investigated the heritage of the historians starting from 1996. V. Lutsenko paid attention to the new outlook of Ukrainian and Russian colleges at agrarian programs of Kadets, SRs, Social Democrats and Monarchists in the works of N. Bychkova, L. Bondarenko, V. Nahainyk, M. Savchyn, O. Sorokina, V. Susorov and O. Fedkov. Notably, the author within the pages of his article organized a kind of discussion between historians concerning the agrarian program of Constitutional Democrats. While L. Bondarenko and O. Fedkov found the propositions of Kadets on reformist solving of agrarian peasant question (in terms of forced repurchase of the land from pomestchiki (the landlords), rationalization in agricultural management, development of small crediting) to be cautious and reasonable, their "opponents" M. Yakupov and O. Zakharchuk expressed Leninist opinion on the left liberals' program as the counter-revolutionary [1].

The historiography of agrarian issue is represented in broader scale in the common study by Dubinskyi and O. Fedkov. The authors admitted that most of the works mentioned by them reviewed the agrarian question tangentially, within the framework of general information over parties' programs or their generalized aims. The authors paid a detailed attention to characterizing V. Lukianenko's dissertation and O. Fedkov's monograph. At that, the thesis of the first author is estimated as less informative for the historians research subject (agrarian programs of Ukrainian political organizations) since it explores the approaches to solve the agrarian problem from the perspective of different social groups, while the vision of the ways out of this problem by political organizations on the territory of Ukraine was represented only in one chapter [2]. Apparently, such skepticism is caused by the reason that authors of the monograph limited their study to the investigation of the synopsis of V. Lukianenko's thesis.

The works of V. Dubinskyi and O. Fedkov, in fact, interesting by plot and variety of used sources, also worth historiographical. So, I consider that it is necessary to perform a generalized review of Ukrainian historical literature where the process of political thought on the prospects of agrarian reform, qualitative content of agrarian programs as well as their support or disapproval by peasants are analyzed. That's what makes the subject of this article. Comparative analysis of scientific publications is executed in the next order: 1) perception by parties of the reasons of the agrarian peasant issue sharpening under the conditions of the revolution situation forming and during the Russian revolution of $1905 ; 2$ ) stages of agrarian programs forming by Ukrainian and Russian parties and working out of their final versions; hermeneutics of the propositions of agrarian question solving; 3) discussion concerning suggested methods of peasant struggle.

\section{Research results}

The choice of the subject statement should be also explained. In order to do this the difference between the widely used in historical literature notions of "agrarian", "peasant" and "agrarian peasant" issues should be defined. Agrarian question in historical discourse is understood as theorizing of state agrarian policy, ways of its reforming, redistribution of land property and the approaches to do it. Peasant question characterizes the understanding of peasantry legal status, their place in the system of social, labor and economic relations, proprietary rights, peasants' territorial and public self-organization, etc. Agrarian peasant issue reflects the relations between peasants and the state, the processes of the peasants' legal and proprietary statuses alternations and, above all, land use by peasants. Namely in this framework the defined direction of partology is analyzed in this article.

Among all the political parties theoretical basis of Revolutionary Ukrainian Party-Ukrainian Socialist-Revolutionary Labour Party (RUP-USDLP) activity draw the strongest attention of researchers. It is to certain extend determined not only by a relatively long history of this party, but 
also by the ongoing and challenging process of its program document development. For this reason T. Gunchak entitled the party as "odd organization", which came into existence not from the manifestation of its program, which would be a reasonable step, but from general provisions [3]. It influenced the structuring of RUP-USDLP theoretical basis establishment. Particularly, according to A. Pavko, the next stages could be determined in the forming of party's vision of agrarian peasant question: 1) declaring of the limited, as for the left, agrarian transformations (cancellation of redemption payments, liquidation of all the duties and taxes, confiscation of allotted, cloistral lands, liquidation of community) in "RUP program project", 1903; 2) adjustment of "Project" positions on the pages of party body "Selianin" ("The Peasant") (the claims on the state-owned lands were added to the mentioned above list; the lands must have been rented to landless farmers and the money from them must have been intended for public needs), 1903; 3) Project of the RUP platform which took as a model the Erfurt Program of Social Democratic Party of Germany assigned to clear the way to the capitalism in agriculture, transfer the allotted, cabinet, church and cloistral lands to peasants; in same time it leaft the question about the landlords' property, land minicipalization; 4) USDLP program establishment at the end of 1905, which approved the idea of land municipalization and emphasized on the big private owners' lands confiscation [4].

Notably, that the position of the historian concerning the assumption by Ukrainian social democrats of inevitability of capitalistic development in agriculture contradicts the ideology of USDLP of that time. The preamble of their program, in particular, clearly defined the attitude of the party to private property and market economy as a whole: "The abyss between the haves and haves-not is enhanced even more by the crises, which take root in the essence of capitalistic way of production, they... prove that reproduction forces have overgrown it, that private property for the means of production, which has been a method of exploitation of peasants, craftsmen and small sellers makes the output of labours a property of idle capitalists and big landlords. Only the transformation of private property on means of production - land, mines, pits, raw material, machines and means of communication - into public property and transformation of commercial production into social production, which is made for the civil society and by the society representatives themselves - can result in transferring of great production and constant growth of reproductive public labour for those classes that have been exploited, from the sources of poverty and humiliation - to the sources of welfare and all-round harmonious improvement" [5]. Thus, the support of the agriculture capitalization ("annihilation of laws which limit the rights of peasants to manage their land freely; the right of public land redistribution, the right of detachment”) could be estimated not as the party end purpose, but as an intermediate goal, necessary only in order to " abolish all the vestiges of serfdom in agrarian relations". Though, beyond these horizons USDLP had quite generalized vision of agrarian issue in terms of the attitude to the private property and to the capitalism as a whole. In future the liquidation of any kind of economic exploitation, "annihilation of class supremacy and the classes themselves" were supposed [6].

V. Dubinskyi and O. Fedkov also paid attention to the question of the RUP agrarian program evolution: while until 1905 RUP had tended preferably to the thought of land nationalization - its socialization for the state fund with further redistribution between farmers on conditions of rent according to the labour principle (" one should cultivate as many land as he can", annihilation of serfdom vestiges (easements liquidation, return of allotted land cuts (otrezy), then under the influence of Menchviks they standed for its municipalization [7]. Keeping to the Menshevist direction in agrarian peasant question solution by USDLP was marked by P. Shmorhun [8].

New, comparing to the conclusions of A. Pavko, was the analysis performed by V. Dubinskyi and O. Fedkov of USDLP attitude to agrarian peasant question after the end of the revolution. The party laid strictures on Stolypin reform ("paper way to settle agrarian relations"), which, as they convinced, kept landlords ownership and supremacy untouchable, forced peasants to settle on worse lands, use disadvantageous for them services of Peasant bank, sharpened social inequality, didn't take into account the peculiarities of land issue in different parts of the empire. New in the work of V. Dubinskyi and O. Fedkov was their observation that Social Democrats, as well as Ukrainian liberals, focused greatly on the problems of agriculture intensification and crediting, development of cooperation and agricultural education, which, apart from the improvement of 
material situation in the countryside, aimed at the establishment of the party firm basis here: to some extend cooperative activity legalized the operation of USDLP and also provided additional advantages in the development of new party cadres. Moreover, "the group of party theorists" (M. Porsh, V. Sadovskyi, L. Yurkevych) even approved the idea of resettlement policy, criticizing only the measures of its organization. V. Dubinskyi noted that in this direction the party began to favour the cooperation with "middle class" and wealthy peasants, "who made one of the sources of national intelligentsia (therefore, the party active)", which we can connect rather to amplifying right-wing deviation of social democrats than to rational highlighting of key points in party development. Another important moment emphasized by V. Dubinskyi is complete devaluation of national question, which was more and more submitted to "class idea" - the consequence of the limited successes of Ukrainian political forces to streigtforward the peasantry to the path of national struggle [9].

Quite certain is the perception of agrarian peasant question settlement by Spilka (USDUUkrainian Social Democratic Union). The dominant influence of Mensheviks on its activity is defined (it is known that the party didn't have its own separate program - nevertheless it propagated its vision of future agrarian system in the press and leaflets which became the objects of scientific researches). Thus, the land should have been confiscated from the exploiters without compensation and later distributed between the farmers in terms and amounts defined by local peasant committees, which would have been the real owners of the land: "local population through its elected representatives decides what lands and by which lots to give out for the usage by all the peasants, per person and at which lands it is more profitable to cultivate land under the guidance or pretence of people's representatives" - USDU assumed a definite Menshevist position of land municipalization. Other suggestions of the party concerned the return of land cuts, repayment amounts, and defense of agrarian labours' rights (implementation of eight hour shifts, improvement of nutrition and housing conditions). Only the lots of small owners and peasants should have stayed in private property [10].

It is quite easy for the historians to analyze the position of Ukrainian National Party (UNP), above all due to the following two moments: 1) agrarian program of the party was written in detail; 2) its propaganda in the countryside failed, which makes to estimate the suggestions of Ukrainian nationalists exclusively as a theory. The researchers, primarily, agree with the vision of UNP as not only a nationalist party, but also as a socialist party. The later comes from the criticism of capitalism and recognition of the necessity to build socialist regime which were declared in the program [11]. At the same time, the socialism by UNP had the distinctions from the perceptions over future social and political system by other parties, it smoothly interconnected national and social issues. The realization of social and economical policy of the party supposed evolutionary way of social society establishment. This opportunity was put by the theorists of UNP into the dependence from the level of civilization development ("social system... will be joint only by the nations of extremely high culture"), establishment of ethnocratic Ukrainian society, suggesting the usage of the benefits of socialized property to the title nation ("to nationalize land means to make it the property of Ukrainian nation"), of the liberation of Ukraine in general ("until exist the nationsslaves and nations-dominants...till then agrarian question can't be resolved"). The steps to this should lie in the regulation of land rent and, finally, solving of agrarian question - land nationalization for the compensation to Ukrainian owners and without compensation for the outsiders [12]. Hence, the understanding of nationalization by M. Mikhnovsky's followers was quite peculiar and suggested "transfer of land into the property of the nation", which brought the solution of the contradictions over the land into dependence from the prospects of national revolution and rather delayed peasants from independency.

The historians also investigated other suggestions of UNP concerning the improvement of peasants economic conditions by means of minimum program: 1 . Legal regulation of rent relations (rating of rent according to land profitability, abolishment of short-time rent, implementation of countryside arbitration courts for the solving of disputes between landlords and peasants; transformation to rental farming, independence of a renter concerning "the way of business", compensation for the implemented improvements in the rented property). The emphasis on the 
establishment of rental relations must have demonstrated to the peasants the parasitical character of land aristocracy existence. 2. Protection of agrarian workers' labour rights, implementation of labour occupancy safety standards in agriculture [13]. In 1907 UNP proclaimed the task to transfer the landlords lands to peasants on the rights of private property, which was explained by them by "the danger of the Russian (Moskow) Trudoviks" land reform for Ukrainian nation", "the voice of the peasantry itself" and, finally, their own conclusions that "A Ukrainian farmer is not prepared for the socialism" [14]. The last, taking into account the position of Ukrainian peasantry regarding ARPU (All-Russian Peasant Union) could be considered as a vision distinct from the majority of agrarians. Actually, neither first, nor second programs were communicated appropriately to the peasantry due to the scantiness of agitation work, as was stated by the author of the current article and by A. Pavko [15].

In the summing up of UNP program there are two opposite viewpoints. Thrs, H. Kasianov criticized it for "declarativity and crudity" [16]. The second point could be argued since the party in the minimum program part concerning agrarian and labor issues proposed quite rational measures - to observe sanitary labour conditions, to fix working hours, to regulate rental relations. F. Turchenko noted in general considered and well-thought-out character of UNP program [17], which in my opinion, represents another extreme. The difference of common version of land nationalization from nationalization proposed by UNP is not clear. Also the position on the "educational" role of the rent calling to open peasants' eyes to the parasitic character of the landowners is questionable. Indistinctively, exalting the interest of the Ukrainian owners, the party expressed according to the land redemption.

V. Dubinskyi, O. Fedkov and A. Pavko also considered program measures and activity of Socialist Party of Ukraine (SPU). A. Pavko was interested mostly in the nature of the party (the researcher approvingly cited the characteristics given to the Social Party of Ukraine by O. Hermaize "intelligent socialism on the Ukrainian grounds"), its tactical adjustment for the union with other left parties, understanding of the national issue by the party members, polemics of the party with L. Ukrainka and I. Steshenko concerning the prospects of Ukraine independency [18]. V. Dubinskyi, O. Fedkov, on the other hand, made an emphasis on social content of the program. Nevertheless, the historians could hardly get much useful information from the SPU heritage which should be explained by the source data narrowness since the party represented the solution of agrarian and peasant issue as generalized statement. "Project of the Social Party of Ukraine" concerning agrarian sphere proposed only "gradual socialization of the land, means of production and communication; measures for this, in order to simplify for the peasants the transformation to common, public business" [19]. Moreover, in the research work of V. Dubinskyi and O. Fedkov there is a mentioning of peasant issue in the socialists body "Dobra novyna" ("Good news"): the party leaders considered to be necessary to carry out systematic explanatory work among the peasants on the values of socialism, transfer of power to the working class [20].

Agrarian project of Ukrainian Peasant Party (UPP) is scarcely mentioned in the historical literature. This party existed, as it is known, only on paper. The only document evidencing its existence is "Our tasks" (Declaration of the Ukrainian Peasant Party), published in a single issue of the newspaper "Zaporizhia" from $23^{\text {rd }}$ of February 1906. So, the historians must make conclusions on the positions of Ukrainian Peasant Party only out of its platform, which assumed the solution of land question as follows: freely elected Constituent assembly should according to the developed by the Assembly means nationalize all the land founds excluding the lots belonging to small owners (those who have a lot no bigger than established maximum), which should "further stay in their property" [21].

F. Turchenko emphasized active participation of UNP members in the peasant party project support. The editorial office of "Hliborov" ("The Grain Grover") already in November of 1905 appealed for the creation of a separate political organization of agrarians. The logical consequence of this proposition became the proclamation about the creation of new Ukrainian party, which should have defended the interests of Ukrainian peasants [22]. V. Dubinskyi and O. Fedkov having compared the Declaration of Ukrainian Peasant Party and minimum program of Ukrainian 
National Party came to the conclusion that "the peasants" if fact repeated the suggestions of "the nationalists" [23]. Really, the main thesis of the UNP agrarian project "to nationalize land means to make it the property of Ukrainian nations" is adhered in the program of UPP - all the lands should be transferred into "national property of Ukrainian people". Furthermore, quite emphatically in the manner of "the nationalists" sounds the motto to awake class consciousness of peasants [24]. So, V. Dubinskyi, F. Turchenko, O. Fedkov do not deny the hypothesis that M. Mikhnovsky himself could be the author of the program document of the UPP.

Eclectic program of the Social Party of Ukraine, which had place for the pretence to having nationwide character and opposing Ukrainians to Russians, Jews, Polish (social and political masters of Ukrainian nation) and claiming to form labour legislation on the basis of scientific socialism and preservation of small private property, certainly, was subjected to severe criticism from Ukrainian left-wing politics, which was noted by F. Turchenko [25]. In general, the program of the UPP could be characterized as petit bourgeois version of agrarian question solution, since the authors of the documents tended to small-holding parceling in dealing with major land question [26]. This could demonstrate the beginning of a noticeable right-wing deviation in social and political ideology of the nationalists.

The propositions to solve agrarian peasant issue by Ukrainian political centrists - liberals make a separate subject for research. Dynamics of agrarian issue development by left liberals coincides with the transformation of the party general program means, analyzed in the thesis work by S. Ivanytska (Chmyr) and monograph by V. Kolesnyk and L. Mohylnyi: 1) autumn 1904 development of the Ukrainian Democratic Party (UDP) platform; 2) autumn-summer 1905 adoption of the UDP and the Ukrainian Radical Party (URP) programs; 3) September of 1905 country and city congress of Ukrainian democrats, which approved to strive instantly for the confiscation of private, allotted, cabinet and cloistral lands; 4) correction of UDP program by its Poltava community, published on the $27^{\text {th }}$ of November 1905 in the annex to newspaper "Poltavschina" (agrarian issue is covered in the section "Questions economic and financial"); 5) December 1905 - April 1906 - development and adoption of Ukrainian Democratic Radical Party, based on URP platform [27].

In spite of the differences in programs, their agrarian parts by the UDP, the URP and the UDRP are actually similar, though the platform of the URP and the created on its basis program of the UDRP are regarded to be more considered and detailed. Ukrainian left-wing liberal parties, as known, defended the position of land nationalization ("the land belongs to the nation, to all people... is managed by the Parliament or the Sejm": state, allotted, cloistral, church lands should be transferred into regional land fund (URP, UDRP) or into the property of the region, controlled by autonomous regional sejm (UDP); lots belonging to big private owners should pass to that fund (be subordinated to autonomous government bodies) through repurchase operation according to the calculations of "national bank" or with the help of the bodies of local government by the proceeds of the agrarians ("at a low price and not much in the hands of a single person, as much as one family can process") with further distribution between them (landless and land-poor) of land into long-term rent according to the so-called "labour rate" (UDP, URP, UDRP); common (cooperative) use of land was emphasized (URP, UDRP); it was suggested to spread labour legislation at work-hands ("peculiarities which are demanded by the character of agricultural labour") (URP); to develop agrarian and specialized education (UDP, URP, UDRP). Left liberals also proposed to implement the permissible limitation of purchased land per one household (UDP, URP). The rest of the suggestions of radical democrats concerned facilitation of peasants' activity to abolish redemption payments and taxes paid by peasants, legal regulation of rental relations, abolishment of strip holding (URP), protection of agricultural workers labour (UDP) [28]. The UPD suggested to solve agrarian peasant question exclusively by constitutional means through the consensus with all-Russian and regional government authorities. Firstly, Russian legislative body should have developed general principles of agrarian reform conduction. Then national parliament (sejm) should have adapted developed propositions according to local specifics [29]. 
The question of private property institution remained debatable in the groundwork of left liberals. The members of the UDRP, as demonstrated by O. Fedkov and V. Dubinskyi, didn't arrive at a consensus - ultimately the question should have been decided by village committees [30]. This position with slight variations was common for the UDP, the URP, the UDRP and the Society of Ukrainian Progressists (TUP) - the last mentioned in addition to the agrarian program of the UDRP strived to "abolish forced land arrangement with its isolated farmsteads and otrubs") [31].

Ukrainian historians describing the propositions of left liberals concerning the solution of land question mostly agree on reasonable arguments of programs developers about the expediency of compensation for land, definition of the upper limit and state regulation of land usage. Particularly, V. Kolesnyk, L. Mohylnyi and V. Moisiienko explained it by the understanding by centrists of temporariness of even land distribution. Since together with democratic growth further land parceling occurs, it was suggested that the land should be owned by those, who work on it. In such a way, lands could be transferred from one user to another - state lands were not subjected to privatization [32].

Another interesting aspect of our subject is the level of interrelation between agrarian programs of the national left liberals and Russian parties. There is a settled outlook that socialeconomic propositions of the UDP, URP and the UDRP had rather inconsiderable novelty and according to the main points in general they coincides with the Kadets' platform. But in contemporary historiography such viewpoint is not as unanimous. For example V. Moisiienko analyzing agrarian projects summarized that Ukrainian liberal parties didn't fall back to thoughtless copying of others' projects or theories, but tried to work out their own forms and methods of state political organization, of national and social liberation [33]. Opposing position is hold by V. Kolesnyk, L. Mohylnyi and A. Pavko, who estimate the program of URP as eclectics of theoretical best practices of different parties. Yet they released UDP from such criticism [34]. I think that compilativity, insufficient elaboration and specification of agrarian programs were the common features of centrist parties platforms. Moreover, this peculiarity was preserved after their joining, which certainly influenced the poor success of left liberals in the agitation of population.

S. Donchenko considers that it is economic program of Ukrainian liberals that reflects their dual nature. The claim of the UDRP to submit land fund to regional authorities lays beyond "Kadet nature" of its program and is close to the SRs' "socialization". In general, in agrarian peasant question radical democrats took a position closer to the claims of Russian Social Democrats and Social Revolutionaries, in spite of the declared proposition of mandatory land buyout from large private owners [35].

The above mentioned thought is hard to agree since the SRs suggested transferring lands into the control of the bodies of local governments from democratically organized non-estate country and city communities to regional and central establishments inclusively. At the same time, land issues should have been solved mostly by community, while liberal project supposed to fulfill agrarian reform through representative regulatory bodies, in other words, "in bourgeois way" [36].

Whether it gives grounds to confirm entire devotion of Ukrainian centrists programs to the ideas of liberalism or whether the adjustment for socialism of radical-democrats contradicted market realias and how do historians refer to it? V. Dubinskyi and O. Fedkov in their works come to the conclusion about correspondence of parties statements to the task of capitalism purification: for example, the UDP oriented peasants for "reformatory way of agrarian question solution and adaptation of agriculture to market conditions", the party "wanted to reconcile the interests of landlords and peasants", and the question of compensation for land was explained by "the membership of the party itself, where substantial share was occupied by land owners". Certain material for such thinking is provided rather by disputes over agrarian question conducted by the leaders of radical democrats than by the texts of party programs. Some of their speakers, as demonstrated V. Dubinskyi, considered it was necessary to raise the agrotechnical level of peasant farming and peasants agrarian education (S. Borodaievskyi, B. Hrinchenko, M. Hrushevskyi, S. Yefremov, O. Lototsky, I. Chykalenko), liquidate the community (V. Vasylenko, O. Lototsky), 
protect the rights of agricultural workers (M. Hekhter, B. Hrinchenko, O. Lototsky), define the property right on land as the right to use land, extending this right to the landlords on condition of their consent to do business personally or even keep the land to the landlords in private property within established maximum area (M. Hrushevskyi, V. Domanitskyi, G. Kovalenko, M. Kononenko) [37].

Separate attention V. Dubinskyi paid to the views on agrarian issue of Ukrainian economists and liberal public person M. Tugan-Baranovsky, who suggested executing land nationalization for compensation according to "unchanged conditions of capitalist business since only in this case land reform can be successful". The fulfillment of land buying out the scientist reasoned both by market mechanisms ("land should pay off the mortgage debt rested on it" and by tax reasoning ("land would be subjected by so many rubles of state tax, that it would never be subjected to so many percents in case of its repurchase by ordinary capitalistic way") [38]. In such a way Ukrainian liberals suggested reformist solution of agrarian question, adaptation of agriculture to market conditions of country development - this conclusion made by V. Dubinskyi discords to general purpose of the party to achieve the establishment of socialist regime.

The remarkable thing is that Ukrainian centrists considered capitalism as a temporary phenomenon. In the platform of Kharkiv committee of UDP published on the $25^{\text {th }}$ of October 1905 it was stated: "We are deeply convinced that only at fulfillment of socialist regime, only under the condition of entire fall of bourgeois economic regime and division of the society into classes of exploited and exploiters, people will get a complete possibility of free development in physical, mental and moral senses [39]. Confiscation of allotted, state, church and cloistral lands without compensation and expropriation for compensation of landlords lands must have served to the prevention of peasant degeneration. Traditional vision of peasants on the land as common property of all the working classes ("The land is no one's - the land is the God's and only those who can cultivate it themselves or by the labour of their families can use it") became an ideological justification of such confiscation [40]. This is the evidence of moderate socialist platform of radical democrats. Finally, В. Дубінський та О. Федьков, in one of their publications agreed on the "closeness of separate statements of Ukrainian liberals' agrarian program to Neonarodniki" [41].

Interesting segment of historical partological studies is represented by the ways of agrarian question solving proposed by Ukrainian parties in their programs or appeals. In the activity of the RUP the historiography of the question clearly defines two periods. At the beginning of it functioning RUP proposed to reach the change of agrarian system by means of terror supported by the party in 1902 during the devastations at Left-bank Ukraine, which was explained by V. Borysenko as "relicts of Populism" in the activity of RUP - too attractive seamed the image of Narodniki to a new generation of revolutionists [42]. Imprisonments, which seized the party after suppression of Kharkiv-Poltava uprising, threw cold water on its position concerning violent means of struggle. From now RUP instead of agrarian terror suggested peasants "the most powerful means of struggle with landlords" - strike and boycott (refusal to pay taxes and serve homage) while its political purpose was limited to the task "to earn confidence and respect among the peasants". Already in 1905, V. Golovchenko demonstrated, "Gaslo" ("Motto") opposed these methods to rebellion and extemporaneous revolts, defined as disorganizing measures. Moreover, as revealed H. Kasianov, "The Project of the RUP Program" appealed peasants for the organization of demonstrations. Reasonability of terror was accepted in political agitation, but actually the party didn't use it [43]. Among all the mentioned above measures RUP the most effectively approached strikes. Already in 1903, as pointed out by V. Borysenko, it organized and headed a series of considerable strikes of agricultural workers at Yekaterinoslav, Kyiv, Poltava and Podolia Governorates. This experience was later successfully used by the USDU [44].

As demonstrated by the historians, the party tactics still didn't change during the revolution of 1905-1907 years. Analyzing party tactics during this time, H. Kasianov concluded that the UDRLP set an ambitious task not so much to select the most effective methods of struggle for the peasantry as to turn peasants' energy into organized forms of struggle [45]. Really, in spite of the sharpening of social contradictions, the RUP strongly declaimed spontaneous peasant actions, 
which was embodied in the resolution of the II party Congress "On the Attitude to Spontaneous Movements". Alternative to this was seen by the party in the organization of strike movement. It was new, as shown by V. Dubinskyi and O. Fedkov, that the USDLP supported the activity of AllRussian Peasant Union, which was seen by the party as the foundation able to turn revolutionary energy of peasantry from demolition to sound social and political movement [46].

Apparently, it was indecision in work with peasants that didn't allow the RUP-USDLP to achieve considerable successes in the extension of their influence on the province. Already in 1906 the clear superiority in the countryside was achieved by Spilka. V. Kolesnyk, L. Mohylnyi, V. Dubinskyi and O. Fedkov worthily described the methods of struggle proposed by this party. The tactics of the USDU involved the combination of peaceful and violent ways of struggle. Thus, the realization of labour rights of work-hands could have been generally achieved in peaceful way, including strike, which was considered the most effective one of them, the agrarian tasks, on the other hand, should have been solved by revolutionary means. Important role was devoted to the union of workers and peasants, to the armament of people. The researchers distinguished the following main well-proven methods of the USDS's struggle: strike, fighting high land rent prices, refusal from provision of recruits to army. Besides, they gave detailed clarifications on how to arrange protest movements. In the article "How to Take the Land away from the Landlords", published in the USDS's "Lystok Pravdy" ("The Leaflet of the Truth") peasants were explained the connection of land question and revolution struggle, how to organize a strike and what claims should be demanded of the landlords. Furthermore, Spilka, unlike USDLP supported pogrom movement in the countryside, which, evidently, enlarged their popularity among peasants. The last, as shown by the researches, went beyond the scope of guiding vision in social-democracy about the character of agrarian movement. The ideas of Spilka were extended by the means of written and oral agitation, creation of clubs, libraries, organization of meetings, conferences and public readings [47].

Unlike left parties, the liberals, as demonstrated by V. Dubinskyi and O. Fedkov propagated exclusively peaceful methods of struggle. Agrarian peasant question must have been solved in terms of legislative activity, and until that, the leaders of middle-road parties suggested to develop agrarian education, release peasants from bureaucracy custody, organize strikes ("in such a manner it is better to fight with the enemy and only when he is prepared"), create cooperative enterprises, favour to the formation of bottom structures of the all-Russian Peasant Union and calling of Ukrainian Peasant Congress on the creation of separate Ukrainian peasant organization, which, keeping the relations with the ARPU, should have strived for the turning of peasant movement in Ukraine to peaceful way and, what's the most important, transfer peasant desires to attain land and liberty into national stream [48]. Thought, unlike Ukrainian socialistic parties, left liberals still couldn't reach out peasants by these means. Objective reasons for centrists' transferring into fringe politicians, as shown byA. Pavko, were party promiscuity, its weak connections with masses, which was caused by the failure to work in clandestine conditions and, finally, by the small quantity of the liberals [49].

\section{Conclusion}

The subject of the agrarian peasant question in the programs of Ukrainian parties, reviewed in specialized or general historical studies, is rather abundant with information and assumptions. In its turn, it is discomposed into subtopics according to the place of the party in the political spectrum (left-wing, middle-road or right-wing parties) or how it concerns specific political power. In spite of the different objects of research, their depth level and the research field of the agrarian peasant question solution conceptions, all these scientific explorations could be consolidated according to the range of common features. First of all, the methodology of research in post-Soviet historiographical period changed in the sense of shifting away from the analysis of parties programs as doubtless evidence of the pureness of their ideological representativeness. Now critical understanding of the agrarian parts of the party programs is done only with the obligatory involvement of other data - party proclamations, appeals, congresses stenographs, memoirs, which considerably extend and elaborate the research. Secondly, in order to clarify the future agrarian system foreseen by the parties it is important to define their ideological and theoretical identification - commitment to Marxism, Narodnichestvo, Liberalism, Moderate Socialism. 
However, as was shown above, the question on the true position of left liberals with not completely defined status of the party with socialistic direction is still debatable. Thirdly, important is foregrounding at practical part of parties vision of agrarian system changes - how to attain changes to the good for indigent peasants. Without placing such emphasizes the study of the agrarian peasant question concepts becomes abstractive, meager, devoid of problem character.

Though the monograph of V. Dubinskyi and O. Fedkov, often referred to in this article, being the latest and the most substantial, crests all the post-Soviet period of the subject historiography, this work is definitely not final. In the historiography of the problem of working out by the parties of the ways of agrarian peasant issue solving the questions of the comparative analysis of agrarian sections of parties programs and other theoretical concepts in terms of their economical practicability are still open. The comparison of certain suggestions of Ukrainian parties with the realization of similar measures during conduction of agrarian reforms in other countries is also essential. Such rationalization of the problem demands interdisciplinary approach and addressing to simulation method. Such approach will provide clarification on the quality of the agrarian changes propositions, reasons of their popularity or, conversely, of their disapproval.

\section{References:}

Lutsenko V. P. Politychni partiyi, rukhy, hromads'ki orhanizatsiyi v Ukrayini: istoriya ta suchasnist' // Visnyk Kharkivs'koho universytetu. Seriya: Istoriya Ukrayiny. 1996. № 387. S. 48-49.

Dubins'kyy V. A. Ahrarne pytannya Naddnipryans'koyi Ukrayiny v ukrayins'kiy hromads'kopolitychniy dumtsi u 1890-ti - 1917 roky: Dys... kand. nauk: 07.00.01. Kam"yanets'-Podil's'kyy, 2009. S. 25-30.

Hunchak T. Ukrayina: Persha polovyna XX st.: Narysy politychnoyi istoriyi. K.: Lybid', 1993. S. 37.

Pavko A. I. Politychni partiyi, orhanizatsiyi v Ukrayini: kinets' XIX - pochatok XX stolittya: zarodzhennya, evolyutsiya, diyal'nist', istorychna dolya. Kinets' XIX stolittya - lyutyy $1917 \mathrm{r}$. K.: Znannya Ukrayiny, 1999. S. 74-75, 126-133.

Russian State Archive of Socio-Political History. F. 334. Op. 1. D. 5. L. 6.

Bahatopartiyna ukrayins'ka derzhava na pochatku XX st.: Prohramni dokumenty pershykh ukrayins'kykh politychnykh partiy. K.: Poshuk, 1992. S. 8, 11.

Dubins'kyy V. A., Fed'kov O. M. Ahrarne pytannya v politychnykh kontseptsiyakh ukrayins'kykh partiy i hromads'kykh orhanizatsiy Naddnipryanshchyny naprykintsi XIX - na pochatku XX st.: monohrafiya. Kam"yanets'-Podil's'kyy: PP «Medobory-2006», 2012. S. 99.

Shmorhun P. M. Politychni partiyi Ukrayiny na pochatku XX st.: sotsial'nyy sklad, chysel'nist', typolohiya // Naukovi pratsi z pytan' politychnoyi istoriyi. 1992. Vyp. 172. S. 23.

Dubins'kyy V. A. Ahrarne pytannya Naddnipryans'koyi Ukrayiny v ukrayins'kiy hromads'kopolitychniy dumtsi u 1890-ti - 1917 roky: Dys... kand. nauk: 07.00.01. Kam"yanets'-Podil's'kyy, 2009. S. 57-65, 80-89; Dubins'kyy V. A., Fed'kov O. M. Ahrarne pytannya v politychnykh kontseptsiyakh ukrayins'kykh partiy i hromads'kykh orhanizatsiy Naddnipryanshchyny naprykintsi XIX - na pochatku XX st.: monohrafiya. Kam"yanets'-Podil's'kyy: PP «Medobory-2006», 2012. S. 160-169; Dubins'kyy V. A. USDRP pro shlyakhy rozv"yazannya ahrarnoho pytannya u mizh revolyutsiynyy period (1907-1917 rr.) // Ukrayins'kyy selyanyn. 2008. № 11. S. 227-230; Fed'kov O. M., Dubins'kyy V. A. Ahrarne pytannya $\mathrm{v}$ prohramnykh dokumentakh natsional'nykh politychnykh orhanizatsiy Naddnipryans'koyi Ukrayiny u 90-kh rokakh XIX st. // Zbirnyk naukovykh prats' «Politolohichni studiyi». 2013. Vyp. 3. S. 138; Fed'kov O. M., Dubins'kyy V. A. Formuvannya ahrarnykh prohram ukrayins'kykh sotsialistychnykh partiy Naddnipryanshchyny na pochatku XX st. // Zbirnyk naukovykh prats' «Politolohichni studiyi». 2010. Vyp. 1. S. 116-122.

Kolesnyk V.F., Mohyl'nyy L. P. Politychni partiyi ta suspil'no-politychni rukhy v Ukrayini naprykintsi XIX - na pochatku XX stolittya: Navchal'nyy posibnyk. K.: Vydavnycho-polihrafichnyy tsentr «Kyyivs'kyy universytet», 2007. S. 112; Pavko A. I. Politychni partiyi, orhanizatsiyi v Ukrayini: kinets' XIX - pochatok XX stolittya: zarodzhennya, evolyutsiya, diyal'nist', istorychna dolya. Kinets' XIX stolittya - lyutyy 1917 r. K.: Znannya Ukrayiny, 1999. S. 143; Fed'kov O. M., Dubins'kyy V.A. Formuvannya ahrarnykh prohram ukrayins'kykh sotsialistychnykh partiy Naddnipryanshchyny na pochatku XX st. // Zbirnyk naukovykh prats' «Politolohichni studiyi». 2010. Vyp. 1. S. 125-126; Fed'kov O. M., Dubins'kyy V. A. Ukrayins'ka sotsial-demokratychna Spilka: shlyakhy rozv"yazannya 
ahrarnoho pytannya (za materialamy hazety «Pravda») // Naukovi pratsi Kam"yanets'-Podil's'koho derzhavnoho universytetu: Istorychni nauky. 2005. T. 14. S. 246-253.

Dubins'kyy V. A., Fed'kov O. M. Ahrarne pytannya v politychnykh kontseptsiyakh ukrayins'kykh partiy i hromads'kykh orhanizatsiy Naddnipryanshchyny naprykintsi XIX - na pochatku XX st.: monohrafiya. Kam"yanets'-Podil's'kyy: PP «Medobory-2006», 2012. S. 114-115; Kolesnyk V. F., Mohyl'nyy L. P. Politychni partiyi ta suspil'no-politychni rukhy v Ukrayini naprykintsi XIX - na pochatku XX stolittya: Navchal'nyy posibnyk. K.: Vydavnycho-polihrafichnyy tsentr «Kyyivs'kyy universytet», 2007. S. 103; Kudinov D. Ahrarni prohramy ukrayins'kykh politychnykh partiy naperedodni i v period demokratychnoyi revolyutsiyi 1905-1907 rokiv // Materialy III Volyns'koyi Mizhnarodnoyi istoryko-krayeznavchoyi konferentsiyi (Zhytomyr, 12-13 lystopada 2010 r.). Zhytomyr: Vyd-vo ZhDU im. I. Franka, 2010. S. 64; Pavko A. I. Politychni partiyi, orhanizatsiyi v Ukrayini: kinets' XIX - pochatok XX stolittya: zarodzhennya, evolyutsiya, diyal'nist', istorychna dolya. Kinets' XIX stolittya - lyutyy 1917 r. K.: Znannya Ukrayiny, 1999. S. 83.

Istoriya ukrayins'kykh politychnykh partiy: Khrestomatiya-posibnyk. Kinets' XIX - 1917 r. - K.: Vyd-vo Yevrop. un-tu, 2003. Ch. 1. S. 87-90.

Dubins'kyy V. A. Ahrarne pytannya Naddnipryans'koyi Ukrayiny v ukrayins'kiy hromads'kopolitychniy dumtsi u 1890-ti - 1917 roky: Dys... kand. nauk: 07.00.01. Kam"yanets'-Podil's'kyy, 2009. S. 53-99; Dubins'kyy V. A., Fed'kov O. M. Ahrarne pytannya v politychnykh kontseptsiyakh ukrayins'kykh partiy i hromads'kykh orhanizatsiy Naddnipryanshchyny naprykintsi XIX - na pochatku XX st.: monohrafiya. Kam"yanets'-Podil's'kyy: PP «Medobory-2006», 2012. S. 110-112; Kudinov D. V. Ahrarni prohramy ukrayins'kykh politychnykh partiy naperedodni i v period burzhuaznodemokratychnoyi revolyutsiyi 1905-1907 rr. // Sums'ka starovyna. 2007. № XXIII. S. 39-40; Dubins'kyy V. A. Ahrarna doktryna Ukrayins'koyi narodnoyi partiyi // Naukovi pratsi Kam"yanets'Podil's'koho derzhavnoho universytetu: Istorychni nauky. 2003. T. 11. S. 161-165; Dubins'kyy V. A. Ahrarne pytannya v ukrayins'kiy hromads'ko-politychniy dumtsi Naddnipryanshchyny 90-kh rr. XIX st. // Naukovi pratsi Kam"yanets'-Podil's'koho derzhavnoho universytetu: Zbirnyk za pidsumkamy zvitnoyi naukovoyi konferentsiyi vykladachiv i aspirantiv. Vyp. 6. V 3-kh tomakh. 2007. T. 1. S. 11-13.

Dubins'kyy V. A. Ahrarna doktryna Ukrayins'koyi narodnoyi partiyi // Naukovi pratsi Kam"yanets'-Podil's'koho derzhavnoho universytetu: Istorychni nauky. 2003. T. 11. S. 163-164; Turchenko F. H. Mykola Mikhnovs'kyy: Zhyttya i Slovo. K.: Heneza, 2006. S. 166.

Kudinov D. V. Ahrarni prohramy ukrayins'kykh politychnykh partiy naperedodni i v period burzhuazno-demokratychnoyi revolyutsiyi 1905-1907 rr. // Sums'ka starovyna. 2007. № XXIII. S. 40; Pavko A. I. Politychni partiyi, orhanizatsiyi v Ukrayini: kinets' XIX - pochatok XX stolittya: zarodzhennya, evolyutsiya, diyal'nist', istorychna dolya. Kinets' XIX stolittya - lyutyy 1917 r. K.: Znannya Ukrayiny, 1999. S. 146.

Kas'yanov H. V. Ukrayins'ka intelihentsiya na rubezhi XX - XIX stolit': sotsial'no-politychnyy portret. K.: Lybid', 1993. S. 157.

Turchenko F. H. Mykola Mikhnovs'kyy: Zhyttya i Slovo. K.: Heneza, 2006. S. 150.

Pavko A. I. Politychni partiyi, orhanizatsiyi v Ukrayini: kinets' XIX - pochatok XX stolittya: zarodzhennya, evolyutsiya, diyal'nist', istorychna dolya. Kinets' XIX stolittya - lyutyy 1917 r. K.: Znannya Ukrayiny, 1999. S. 86-90.

Istoriya ukrayins'kykh politychnykh partiy: Khrestomatiya-posibnyk. Kinets' XIX - 1917 r. - K.: Vyd-vo Yevrop. un-tu, 2003. Ch. 1. S. 59.

Dubins'kyy V. A., Fed'kov O. M. Ahrarne pytannya v politychnykh kontseptsiyakh ukrayins'kykh partiy i hromads'kykh orhanizatsiy Naddnipryanshchyny naprykintsi XIX - na pochatku XX st.: monohrafiya. Kam"yanets'-Podil's'kyy: PP «Medobory-2006», 2012. S. 94-95.

«Samostiyna Ukrayina»: Zbirnyk prohram ukrayins'kykh politychnykh partiy pochatku XX st. Ternopil': Redaktsiyno-vydavnychyy viddil upravlinnya po presi, 1991. S. 76-77.

Turchenko F. H. Mykola Mikhnovs'kyy: Zhyttya i Slovo. K.: Heneza, 2006. S. 158.

Dubins'kyy V. A., Fed'kov O. M. Ahrarne pytannya v politychnykh kontseptsiyakh ukrayins'kykh partiy i hromads'kykh orhanizatsiy Naddnipryanshchyny naprykintsi XIX - na pochatku XX st.: monohrafiya. Kam"yanets'-Podil's'kyy: PP «Medobory-2006», 2012. S. 115.

Istoriya ukrayins'kykh politychnykh partiy: Khrestomatiya-posibnyk. Kinets' XIX - $1917 \mathrm{r}$. - K.: Vyd-vo Yevrop. un-tu, 2003. Ch. 1. S. 90; «Samostiyna Ukrayina»: Zbirnyk prohram ukrayins'kykh politychnykh partiy pochatku XX st. Ternopil': Redaktsiyno-vydavnychyy viddil upravlinnya po presi, 1991. S. 75.

Zhuk A. (A. I.) Nova partiya // Vil'na Ukrayina. 1906. № 4. S. 47-49; Turchenko F. H. Mykola Mikhnovs'kyy: Zhyttya i Slovo. K.: Heneza, 2006. S. 158. 
Kudinov D. V. Ahrarni prohramy ukrayins'kykh politychnykh partiy naperedodni i v period burzhuazno-demokratychnoyi revolyutsiyi 1905-1907 rr. // Sums'ka starovyna. 2007. № XXIII. S. 44.

Kolesnyk V. F., Mohyl'nyy L. P. Ukrayins'ki liberal'no-demokratychni partiyi v Rosiys'kiy imperiyi na pochatku XX stolittya: Monohrafiya. K.: Vydavnycho-polihrafichnyy tsentr «Kyyivs'kyy universytet», 2005. S. 110; Chmyir S. G. Ukrainskaya demokratichesko-radikalnayapartiya: istoki, organizatsiya, programma, taktika (90-e gg. XIX v. - 1908 g.): Dis... kand. ist. nauk: 07.00.02. M., 1994. S. 102-147.

Dubins'kyy V. A. Ahrarne pytannya v prohramnykh dokumentakh ukrayins'kykh liberal'nykh partiy Naddnipryanshchyny na pochatku XX st. // Visnyk Kam 'yanets'-Podil's'koho natsional'noho universytetu imeni Ivana Ohiyenka. Istorychni nauky. 2008. Vyp. 1. S. 86-98; Istoriya ukrayins'kykh politychnykh partiy: Khrestomatiya-posibnyk. Kinets' XIX - 1917 r. - K.: Vyd-vo Yevrop. un-tu, 2003. Ch. 1. S. 181, 185-186, 222, 235; Kolesnyk V. F., Mohyl'nyy L. P. Ukrayins'ki liberal'no-demokratychni partiyi v Rosiys'kiy imperiyi na pochatku XX stolittya: Monohrafiya. K.: Vydavnycho-polihrafichnyy tsentr «Kyyivs'kyy universytet», 2005. S. 128-129; Kolesnyk V. F., Mohyl'nyy L. P. Politychni partiyi ta suspil'no-politychni rukhy v Ukrayini naprykintsi XIX - na pochatku XX stolittya: Navchal'nyy posibnyk. K.: Vydavnycho-polihrafichnyy tsentr «Kyyivs'kyy universytet», 2007. S. 120-124; Moysiyenko V. M. Liberal'ni proekty vyrishennya ahrarnoho pytannya na pochatku XX st. // Problemy istoriyi Ukrayiny XIX - pochatku XX st. 2011. Vyp. XVIII. S. 196-198; Pavko A. I. Politychni partiyi, orhanizatsiyi v Ukrayini: kinets' XIX - pochatok XX stolittya: zarodzhennya, evolyutsiya, diyal'nist', istorychna dolya. Kinets' XIX stolittya - lyutyy 1917 r. K.: Znannya Ukrayiny, 1999. S. 93, 150-153; Tymoshenko O. Obstoyuvannya idey federalizmu liberal'no-demokratychnymy partiyamy Naddnipryans'koyi Ukrayiny na pochatku XX stolittya // Problemy humanitarnykh nauk: Naukovi zapysky Drohobyts'koho derzhavnoho pedahohichnoho universytetu imeni Ivana Franka. 2010. Vyp. 26: Istoriya. S. 34, 37; Chmyir S. G. Ukrainskaya demokratichesko-radikalnayapartiya: istoki, organizatsiya, programma, taktika (90-e gg. XIX v. - 1908 g.): Avtref. dis... kand. ist. nauk: 07.00.02. M., 1994. S. 17.

Chmyir S. G. Ukrainskaya demokratichesko-radikalnayapartiya: istoki, organizatsiya, programma, taktika (90-e gg. XIX v. - 1908 g.): Dis... kand. ist. nauk: 07.00.02. M., 1994. S. 159.

Fed'kov O. M., Dubins'kyy V. A. Ukrayins'ki liberaly pro shlyakhy i zasoby vrehulyuvannya ahrarnykh vidnosyn na pochatku XX st. $\mathrm{v}$ Naddnipryanshchyni// Zbirnyk naukovykh prats' «Politolohichni studiyi». 2011. Vyp. 2. S. 167.

Dubins'kyy V. A. Ahrarne pytannya Naddnipryans'koyi Ukrayiny v ukrayins'kiy hromads'kopolitychniy dumtsi u 1890-ti - 1917 roky: Avtoref... kand. nauk: 07.00.01. Kam"yanets'-Podil's'kyy, 2009. S. 11; Dubins'kyy V. A. Ahrarne pytannya v prohramnykh dokumentakh Ukrayins'koyi demokratychnoyi partiyi // Ukrayins'kyy selyanyn. 2002. № 5. S. 62-63; Dubins'kyy V. A. Ahrarne pytannya $\mathrm{v}$ prohramnykh dokumentakh ukrayins'kykh liberal'nykh partiy Naddnipryanshchyny na pochatku XX st.// Visnyk Kam `yanets'-Podil's'koho natsional'noho universytetu imeni Ivana Ohiyenka. Istorychni nauky. 2008. Vyp. 1. S. 86-98; Dubins'kyy V. A. Ukrayins'ki liberal'ni kola u poshukakh shlyakhiv rozv"yazannya ahrarnoho pytannya (1907-1917 rr.)// Naukovi pratsi Kam"yanets'-Podil's'koho natsional'noho universytetu: Zbirnyk za pidsumkamy zvitnoyi naukovoyi konferentsiyi vykladachiv i aspirantiv, prysvyachenyy 90-richchyu Kam"yanets'-Podil's'koho natsional'noho universytetu. Vyp. 7. U 5-ty tomakh. 2008. T. 1. S. 28; Dubins'kyy V. A. Ukrayins'ka liberal'na kontseptsiya rozv"yazannya ahrarnoho pytannya v Naddnipryanshchyni mizh revolyutsiynoyi doby (1907-1917 rr.) // Naukovi pratsi Kam"yanets'-Podil's'koho natsional'noho universytetu im. Ivana Ohiyenka. Istorychni nauky. 2011. № 21. S. 266.

Kolesnyk V. F., Mohyl'nyy L. P. Ukrayins'ki liberal'no-demokratychni partiyi v Rosiys'kiy imperiyi na pochatku XX stolittya: Monohrafiya. K.: Vydavnycho-polihrafichnyy tsentr «Kyyivs'kyy universytet», 2005. S. 128; Moysiyenko V. M. Liberal'ni proekty vyrishennya ahrarnoho pytannya na pochatku XX st. // Problemy istoriyi Ukrayiny XIX - pochatku XX st. 2011. Vyp. XVIII. S. 197.

Moysiyenko V. M. Liberal'ni proekty vyrishennya ahrarnoho pytannya na pochatku XX st.// Problemy istoriyi Ukrayiny XIX - pochatku XX st. 2011. Vyp. XVIII. S. 198.

Kolesnyk V. F., Mohyl'nyy L. P. Politychni partiyi ta suspil'no-politychni rukhy v Ukrayini naprykintsi XIX - na pochatku XX stolittya: Navchal'nyy posibnyk. K.: Vydavnycho-polihrafichnyy tsentr «Kyyivs'kyy universytet», 2007. S. 122; Manifesty politicheskih sil // Pervyj shturm. M.: Molodaja gvardija, 1990. S. 539; Pavko A. I. Politychni partiyi, orhanizatsiyi v Ukrayini: kinets' XIX pochatok XX stolittya: zarodzhennya, evolyutsiya, diyal'nist', istorychna dolya. Kinets' XIX stolittya lyutyy 1917 r. K.: Znannya Ukrayiny, 1999. S. 92-94, 149-151.

Donchenko S. P. Agrarne pitannya v programnih dokumentah polItichnih partiy Ukrayini (pochatok XX st.) // Naukovi pratsi Istorichnogo fakultetu ZDU. 2003. Vip. XVI. S. 111; 
Donchenko S. P. LIberalnI partiyi UkraYini. 1900-1920 rr.: Avtoref. dis... dokt. Ist. nauk: 07.00.01. Dnipropetrovsk, 2006. S. 19.

Pamjatnaja knizhka socialista-revoljucionera. Vyp. 1. B.m.: PSR, 1911. S. 8-9.

Dubins'kyy V. A. Ahrarne pytannya Naddnipryans'koyi Ukrayiny v ukrayins'kiy hromads'kopolitychniy dumtsi u 1890-ti - 1917 roky: Dys... kand. nauk: 07.00.01. Kam"yanets'-Podil's'kyy, 2009. S. 100-129; Dubins'kyy V. A. Ahrarne pytannya v prohramnykh dokumentakh ukrayins'kykh liberal'nykh partiy Naddnipryanshchyny na pochatku XX st.// Visnyk Kam 'yanets'-Podil's'koho natsional'noho universytetu imeni Ivana Ohiyenka. Istorychni nauky. 2008. Vyp. 1. S. 92-93; Dubins'kyy V. A. Ukrayins'ka liberal'na kontseptsiya rozv"yazannya ahrarnoho pytannya v Naddnipryanshchyni mizh revolyutsiynoyi doby (1907-1917 rr.)// Naukovi pratsi Kam"yanets'Podil's'koho natsional'noho universytetu im. Ivana Ohiyenka. Istorychni nauky. 2011. № 21. S. 266-267, 270; Fed'kov O. M., Dubins'kyy V. A. Ukrayins'ki liberaly pro shlyakhy i zasoby vrehulyuvannya ahrarnykh vidnosyn na pochatku XX st. $\mathrm{v}$ Naddnipryanshchyni// Zbirnyk naukovykh prats' «Politolohichni studiyi». 2011. Vyp. 2. S. 155.

Dubins'kyy V. A. Ahrarne pytannya Naddnipryans'koyi Ukrayiny v ukrayins'kiy hromads'kopolitychniy dumtsi u 1890-ti - 1917 roky: Dys... kand. nauk: 07.00.01. Kam"yanets'-Podil's'kyy, 2009. S. 116-117.

State Archive of the Russian Federation. F. 202, Op. 235, D. 25, Ch. 41, L. 37.

Manifesty politicheskih sil // Pervyj shturm. M.: Molodaja gvardija, 1990. S. 539.

Fed'kov O. M., Dubins'kyy V. A. Ukrayins'ki liberaly pro shlyakhy i zasoby vrehulyuvannya ahrarnykh vidnosyn na pochatku XX st. $\mathrm{v}$ Naddnipryanshchyni// Zbirnyk naukovykh prats' «Politolohichni studiyi». 2011. Vyp. 2. S. 156.

Borysenko V. A. Do pytannya pro Revolyutsiynu ukrayins'ku partiyu // Naukovi pratsi z pytan' politychnoyi istoriyi. 1991. Vyp. 169. S. 132.

Dubins'kyy V. A., Fed'kov O. M. Ahrarne pytannya v politychnykh kontseptsiyakh ukrayins'kykh partiy i hromads'kykh orhanizatsiy Naddnipryanshchyny naprykintsi XIX - na pochatku XX st.: monohrafiya. Kam"yanets'-Podil's'kyy: PP «Medobory-2006», 2012. S. 92; Holovchenko V. Vid «Samostiynoyi Ukrayiny» do Soyuzu vyzvolennya Ukrayiny: Narysy z istoriyi ukrayins'koyi sotsialdemokratiyi pochatku XX st. Kharkiv: Maydan, 1996. S. 25, 65; Kas'yanov H. V. Ukrayins'ka intelihentsiya na rubezhi XX - XIX stolit': sotsial'no-politychnyy portret. K.: Lybid', 1993. S. 149.

Borysenko V. A. Do pytannya pro Revolyutsiynu ukrayins'ku partiyu // Naukovi pratsi z pytan' politychnoyi istoriyi. 1991. Vyp. 169. S. 130.

Kas'yanov H. V. Ukrayins'ka intelihentsiya na rubezhi XX - XIX stolit': sotsial'no-politychnyy portret. K.: Lybid', 1993. S. 150.

Dubins'kyy V. A., Fed'kov O. M. Ahrarne pytannya v politychnykh kontseptsiyakh ukrayins'kykh partiy i hromads'kykh orhanizatsiy Naddnipryanshchyny naprykintsi XIX - na pochatku XX st.: monohrafiya. Kam"yanets'-Podil's'kyy: PP «Medobory-2006», 2012. S. 103.

Kolesnyk V.F., Mohyl'nyy L. P. Politychni partiyi ta suspil'no-politychni rukhy v Ukrayini naprykintsi XIX - na pochatku XX stolittya: Navchal'nyy posibnyk. K.: Vydavnycho-polihrafichnyy tsentr «Kyyivs'kyy universytet», 2007. S. 112-113; Fed'kov O. M., Dubins'kyy V. A. Formuvannya ahrarnykh prohram ukrayins'kykh sotsialistychnykh partiy Naddnipryanshchyny na pochatku XX st. // Zbirnyk naukovykh prats' «Politolohichni studiyi». 2010. Vyp. 1. S. 123-129.

Dubins'kyy V. A., Fed'kov O. M. Ahrarne pytannya v politychnykh kontseptsiyakh ukrayins'kykh partiy i hromads'kykh orhanizatsiy Naddnipryanshchyny naprykintsi XIX - na pochatku XX st.: monohrafiya. Kam"yanets'-Podil's'kyy: PP «Medobory-2006», 2012. S. 126-127, 131-132, 135-136, 144.

Pavko A. I. Liberal'no-demokratychni partiyi Ukrayiny na pochatku KhKh st.: vynyknennya, evolyutsiya, prohramovi zasady, diyal'nist' // Visnyk Kyyivs'koho natsional'noho universytety. Seriya: istoriya. 1999. Vyp. 48. S. 35. 